\author{
EISSN:2706-7920 ISSN: 2077-4435 \\ DOI: $10.36632 / \mathrm{csi} / 2021.10 .4 .47$ \\ Journal homepage: www.curresweb.com \\ Pages: 556-568
}

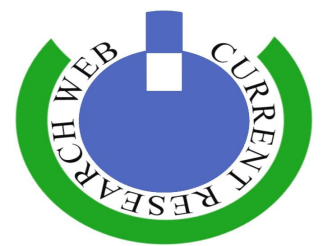

\title{
Effect of Nitrogen and Potassium Fertilization Rates on Vegetative Growth and Cladodes Nutrients Content of Cactus Pear
}

\author{
Amro S. M. Salama, Sahar A. Farid and Osama H.M. El Gammal \\ Plant Production Department, Desert Research Center, Cairo, Egypt.
}

Received: 20 Sept. $2021 \quad$ Accepted: 30 Oct. $2021 \quad$ Published: 05 Nov. 2021

\begin{abstract}
This study was conducted during two consecutive seasons of 2018 and 2019 at cactus pear orchard located on Abu Ghaleb area, "Cairo-Alexandria desert" road about 50km from Cairo, Egypt. The effects of nitrogen fertilization rate i.e. 120,140 and $160 \mathrm{~g} /$ plant/year and potassium fertilization rates i.e. 100,120 and $140 \mathrm{~g} / \mathrm{plant} /$ year as well as their interactions on vegetative growth and cladodes nutrients content of El-shamia cactus pear plants were studied. Fertilization with nitrogen and potassium as well as their interaction improved plant height, plant canopy volume, number of cladodes per plant, cladode length, cladode width, cladode area and content of $\mathrm{N}, \mathrm{P}, \mathrm{Ca}, \mathrm{Mg}, \mathrm{Mn}, \mathrm{Zn}$, $\mathrm{Cu}$ and $\mathrm{B}$ of cladodes. While, nitrogen rates had no significant effect on cladodes $\mathrm{K}$ content in first season and nitrogen at 160 and or 140 gave similar and high values of cladodes Fe content in both seasons. Moreover, potassium rates had no significant effect on cladodes $\mathrm{K}$ content in first season and cladodes $\mathrm{Zn}$ content in both seasons. The interaction between nitrogen at $160 \mathrm{~g} / \mathrm{plant}$ combined with potassium at $140 \mathrm{~g} /$ plant proved to be the most efficient treatment in enhancing growth, nutrients content of cladodes and fruit yield of El-shamia cactus pear plants.
\end{abstract}

Keywords: Opuntia ficus-indica, NK fertilization, vegetative parameters, nutrients content of cladodes.

\section{Introduction}

Cactus pear (Opuntia ficus-indica L.) belong the Cactaceae family and it is commonly known as prickly pear. In arid and semi-arid lands sustainable productivity depends on the cultivation of drought resistant crops (Santini and Carlos, 2013). The most widely grown cultivar of cactus pear in Egypt is El-shamia and Farola. Cactus pear utilized as food, forage, beverages, medicine and dyeing clothes (Leem et al., 2016; Silva et al., 2016 and Gouws et al., 2019). Cactus pear has high adapted to the climatic conditions of the arid and semi- arid region, with tolerance to long periods of drought and high efficiency in water use (Pinheiro et al., 2014; Silva et al., 2015). Moreover, cactus pear have a high potential to grow on severely eroded soils where other crops fail to grow makes it suitable to be grown as food and forage crop in deserts (Lucivania et al., 2018). Cactus pear may be grown as a strategic crop for combating desertification by reducing or partially controlling the soil erosion through its extensive root system (Nefzaoui \& El Mourid, 2009 and Nefzaoui et al., 2014). Furthermore, it has drought tolerance, erratic weather conditions, minimum production cost (Neffar $e t$ al., 2013). For these reasons it as a favorable fruit for marginal land. It could be recommended for resource limited farmers and can grow in poor soil conditions (Nobel and Zutta, 2008). In Egypt, cactus pears are planted by intensive cultivation system from 300 to 500 plants / feddan in new reclamation soils. There is no enough information to produce optimal fruit yield in cactus pear (Zegbe et al., 2014). Cactus pear needs suitable techniques for fertilization management to reach high yield so, it need to nitrogen and potassium fertilization due to a direct relationship among soil minerals content, cladodes minerals content and vegetative growth of cactus pear. However, excessive added of nitrogen could affect vegetative growth, fruit yield and fruit quality (Nobel, 1988 and Claypool et al., 1971). Moreover, nitrogen fertilization increased plant height, plant width, number of cladodes per

Corresponding Author: Amro S.M. Salama, Plant Production Department, Desert Research Center, Cairo, Egypt. E-mail: amrosmss@yahoo.com 
plant and cladode area of cactus pear (Silva et al., 2016a and Neto et al., 2020). Cactus pear plants fertilized with NPK improved plant height, total number of cladodes, cladode area index and cladodes nutrients content (Ramos et al., 2011, Silva et al., 2012 and Silva et al., 2016). In this respect, Stewart et al., (2005) mentioned that fertilizers with N, P and K improved yield by $30-50 \%$. On the other hand, Claassens \& Wessels, 1997; Inglese, 2010 and Arba et al., 2017 worked on cactus pear. They mentioned that NP fertilization improved fruit yield of cactus pear. Moreover, fertilization with NPK improved yield of cactus pear (Mimouni et al., 2013). Also, fertilization with NPK improved vegetative growth and yield. However, $90 \mathrm{~N}-30 \mathrm{P}-30 \mathrm{~K} \mathrm{~kg} /$ ha and $90 \mathrm{~N}-60 \mathrm{P}-60 \mathrm{~K} \mathrm{~kg} / \mathrm{ha}$ treatments improved vegetative growth and yield of cactus pear (Zegbe et al., 2014). Furthermore, cactus pear is a good natural resource still not used in Egypt in spite of it have high potential to supply edible fruit as food for human and a source forage to ruminants in arid and semi-arid area. It important to know the quantities of nitrogen and potassium for plant to enhancement fertilization program and that improved plant and soil fertility. Whereas, decreased in fertility reflected on the production of cactus pear (Dubeux et al., 2006). Stewart et al., (2005) observed that 30 to 50\% of the yields of these crops are attributed to nutrients from fertilizers with $\mathrm{N}, \mathrm{P}$ and $\mathrm{K}$ when they evaluated 362 orchards of cactus pear. In addition, cactus pear needs an appropriate fertilization program for obtaining the maximum yield of cactus pear. Therefore, the aim of this work is to study the effect of nitrogen and potassium fertilization rates on plant growth and nutrients status of cladodes of El-shamia cactus pear.

\section{Materials and Methods}

Following a preliminary experiment carried out during 2017. This study was conducted during two successive seasons of 2018 and 2019 at orchard located on Abu Ghaleb area, "Cairo-Alexandria desert" road about 50km from Cairo, Egypt. Eight years old El-shamia cactus pear plants (Opuntia ficus-indica L.) grown in sandy soil and spaced $3.5 \times 4.0 \mathrm{~m}$ apart (about 300 plants/feddan) subjected to drip irrigation system from well. Physical and chemical analyses of the experimental soil are shown in Table 1. Meanwhile, the chemical analysis of the used water for irrigation is recorded in Table 2. Thirty six plants healthy, nearly uniform in shape and size and productivity and received the same horticultural practices. The present study was a factorial experiment with two factors i.e. the first factor consisted of 3 rates of nitrogen fertilizer (120,140 and $160 \mathrm{~g} / \mathrm{plant})$ and the second one involved 3 rates of potassium fertilizer $(100,120$ and140 g/plant), the experiment was designed as randomized complete block design with four replicates for each treatment and each replicate was represented by one plant.

Table 1: Analysis of experimental soil in 2018 and 2019 seasons.

\begin{tabular}{|c|c|c|c|c|c|c|c|c|c|c|c|c|}
\hline \multirow{2}{*}{$\begin{array}{c}\text { Soil } \\
\text { Depth } \\
\text { (cm) }\end{array}$} & \multirow[b]{2}{*}{$\begin{array}{c}\text { Texture } \\
\text { Class }\end{array}$} & \multirow{2}{*}{$\begin{array}{c}\text { pH } \\
\text { Soil } \\
\text { past }\end{array}$} & \multirow[b]{2}{*}{$\begin{array}{c}\text { E.Ce } \\
\left(\mathrm{dSm}^{-1}\right)\end{array}$} & \multirow{2}{*}{$\begin{array}{c}\text { Organic } \\
\text { matter } \\
\%\end{array}$} & \multicolumn{4}{|c|}{ Soluble cations (meq/l) } & \multicolumn{4}{|c|}{ Soluble anions (meq/l) } \\
\hline & & & & & $\begin{array}{c}\text { Ca } \\
++\end{array}$ & $\mathbf{K}^{+}$ & $\mathrm{Na}^{+}$ & $\mathbf{M g}^{++}$ & $\mathrm{Cl}^{-}$ & $\mathrm{SO}_{4}{ }^{=}$ & $\mathrm{HCO}_{3}^{-}$ & $\mathrm{CO}_{3}=$ \\
\hline $0-30$ & Sand & 7.0 & 1.6 & 0.19 & 7 & 0.4 & 5 & 3.6 & 6 & 7 & 3 & - \\
\hline $30-60$ & Sand & 7.5 & 1.3 & 0.18 & 1.2 & 0.2 & 0.7 & 0.9 & 0.6 & 1.9 & 0.5 & - \\
\hline
\end{tabular}

Table 2: Chemical analysis of water used for irrigation.

\begin{tabular}{|c|c|c|c|c|c|c|c|c|c|c|}
\hline \multirow[t]{2}{*}{ pH } & \multirow{2}{*}{$\begin{array}{c}\text { E.C. } \\
\text { dSm }^{-1}\end{array}$} & \multirow{2}{*}{$\begin{array}{c}\text { O.M } \\
\%\end{array}$} & \multicolumn{4}{|c|}{ Soluble cations (meq/l) } & \multicolumn{4}{|c|}{ Soluble anions (meq/l) } \\
\hline & & & $\mathrm{Ca}^{++}$ & $\mathbf{M g}^{++}$ & $\mathrm{Na}^{+}$ & $\mathbf{K}^{+}$ & $\mathrm{CO}_{3}{ }^{=}$ & $\mathrm{HCO}_{3}{ }^{-}$ & $\mathrm{Cl}^{-}$ & $\mathrm{SO}_{4}=$ \\
\hline 7.1 & 0.93 & 0.7 & 1.60 & 1.21 & 6.25 & 0.28 & 0 & 0.20 & 8.21 & 0.93 \\
\hline
\end{tabular}

Nitrogen applications were 120,140 and $160 \mathrm{~g} / \mathrm{plant}$, its equivalent 585.3, 682.9 and $780.4 \mathrm{~g} /$ plant from ammonium sulfate $(20.5 \%)$ as a source of nitrogen, respectively. Moreover, potassium applications were 100,120 and $140 \mathrm{~g} /$ plant, its equivalent to $208.3,250.0$ and $291.6 \mathrm{~g} / \mathrm{plant}$ from potassium sulfate $\left(48 \% \mathrm{~K}_{2} \mathrm{SO}_{4}\right)$ as a source of potassium, respectively. Both nitrogen and potassium applications were added at two times, the first time $(50 \%$ of applications fertilizer were added at the last week of February), and the second time (50\% applications fertilizer were added after 3 weeks of full blooming, at the first week of May) in both seasons, fertilizers were added as soil application in $15 \mathrm{~cm}$ depth and $1 \mathrm{~m}$ from the trunk. The ordinary fertilization program which used in the district was $15 \mathrm{~kg} / \mathrm{plant}$ of cattle manure with $0.5 \mathrm{~kg} / \mathrm{plant}$ of triple calcium super phosphate $(45 \%$ 
$\mathrm{P}_{2} \mathrm{O}_{5}$ ) added in the first week of January in trench. Response of cactus pear plants to the two factors and their interaction were evaluated through the following determinations.

\subsection{Vegetative growth}

At the end of September plant height $(\mathrm{cm})$, plant canopy volume $\left(\mathrm{cm}^{3}\right)$, number of new cladodes per plant, cladode length $(\mathrm{cm})$, cladode width $(\mathrm{cm})$, cladode area $\left(\mathrm{cm}^{2}\right)$ were measured and recorded.

\section{Plant canopy volume $\left(\mathrm{m}^{3}\right)$}

Plant canopy volume $\left(\mathrm{m}^{3}\right)$ was calculated according to the formula:

Plant canopy volume $=(\pi)($ tree height $)\left(\right.$ radius $\left.^{2}\right)$

Each tree was measured for crown radius (m) in eight directions (every $45^{\circ}$ ) beginning with magnetic north, around the entire plant circumference. Radiuses were measured from the center of the trunk with a compass and a plummet placed in the most external point of the profile for each considered direction (Smith et al., 1997). The resulting measurements were summed and tree canopy volume was determined.

\section{Cladodes area $\left(\mathrm{cm}^{2}\right)$}

Cladode area was determined adopting the methodology used by Barros et al. (2016).

Cladodes area $\left(\mathrm{cm}^{2}\right)=$ cladode length $(\mathrm{cm}) \times$ cladode width $(\mathrm{cm}) \times 0.693$

Where: 0.693 - correction factor for the ellipse shape of the cladode.

\subsection{Cladodes nutrients content}

Cladode samples were collected for the determination of the contents of macro and micronutrients in the tissue in end of September. 10 samples of cladodes (with approximately $20 \mathrm{~g}$ of mass of cladodes not bearing fruit) were collected from the middle section of the plants per each treatment. Samples were sliced, dried, ground and digested according to Parkinson and Allen (1975). Nitrogen was determined by the micro-kjeldahl method Bremner (1965). Phosphorus was calorimetrically determined using Spekol spectrophotometer wave length 882 UV according to Matt, (1968). Potassium was determined by flame-photometer according to Jackson (1958). Calcium and magnesium were determined by titration against versenate solution (Na-EDTA) method as described by Chapman and Pratt, (1961). Iron, Manganese, Zinc, Copper and Boron were determined by using the Atomic Absorption Spectrophotometer "GBC 932 AA".

\subsection{Statistical Analysis}

The obtained data in 2018 and 2019 seasons were subjected to analysis of variance according to Clarke and Kempson (1997). Means were differentiated using Range test at the 0.05 level (Duncan, 1955).

\section{Results and Discussion}

\subsection{Vegetative growth}

I. Plant height (cm)

Data in table (3) indicate that nitrogen fertilization at $160 \mathrm{~g} / \mathrm{plant}$ enhanced plant height than 140 and $120 \mathrm{~g} / \mathrm{plant}$, respectively. Moreover, $160 \mathrm{~g}$ nitrogen/plant proved superiority in both seasons of study. Moreover, $140 \mathrm{~g}$ potassium/plant enhanced plant height than 120 and $100 \mathrm{~g}$ potassium/plant, respectively. Furthermore, the interaction between nitrogen and potassium fertilization rates exerted that $160 \mathrm{~g}$ nitrogen/plant combined with $140 \mathrm{~g}$ potassium/plant proved to be the most effect combination in enhancing plant height of cactus pear plants. On the contrary, $120 \mathrm{~g}$ nitrogen/plant combined with $100 \mathrm{~g}$ potassium/plant gave the lowest values of plant height during both seasons of study. 
Table 3: Effect of nitrogen and potassium fertilization rates and their interactions on plant height $(\mathrm{cm})$ of El-shamia cactus pear plants (2018 and 2019 seasons).

\begin{tabular}{|c|c|c|c|c|c|c|c|c|}
\hline \multirow{3}{*}{$\begin{array}{c}\text { Nitrogen } \\
\text { rates } \\
(\mathrm{g}) \\
\end{array}$} & \multicolumn{4}{|c|}{2018} & \multicolumn{4}{|c|}{2019} \\
\hline & \multicolumn{4}{|c|}{ Potassium rates(g) } & \multicolumn{4}{|c|}{ Potassium rates(g) } \\
\hline & 100 & 120 & 140 & Mean & 100 & 120 & 140 & Mean \\
\hline 120 & $138.00 \mathrm{i}$ & $144.00 \mathrm{~h}$ & $151.33 \mathrm{~g}$ & $144.44 \mathrm{C}$ & $139.90 \mathrm{i}$ & $146.00 \mathrm{~h}$ & $153.43 \mathrm{~g}$ & $146.44 \mathrm{C}$ \\
\hline 140 & $162.67 \mathrm{f}$ & $170.00 \mathrm{e}$ & $174.33 \mathrm{~d}$ & $169.00 \mathrm{~B}$ & $164.87 \mathrm{f}$ & $172.30 \mathrm{e}$ & $176.73 \mathrm{~d}$ & $171.30 \mathrm{~B}$ \\
\hline 160 & $180.33 \mathrm{c}$ & $186.67 \mathrm{~b}$ & $192.33 \mathrm{a}$ & $186.44 \mathrm{~A}$ & $182.83 \mathrm{c}$ & $189.27 \mathrm{~b}$ & $195.03 \mathrm{a}$ & $189.04 \mathrm{~A}$ \\
\hline Mean & $160.33 \mathrm{C}$ & $166.89 \mathrm{~B}$ & $172.66 \mathrm{~A}$ & & $162.53 \mathrm{C}$ & $169.19 \mathrm{~B}$ & $175.07 \mathrm{~A}$ & \\
\hline
\end{tabular}

Means followed by the same letter (s) within each row, column or interaction are not significantly different at $5 \%$ level.

\section{Plant canopy volume $\left(\mathrm{m}^{3}\right)$}

Data in table (4) demonstrate that nitrogen fertilizer rates exerted increased in plant canopy volume which reached to the maximum values $\left(7.71\right.$ and $\left.8.00 \mathrm{~m}^{3} / \mathrm{plant}\right)$ with the nitrogen fertilizer at $160 \mathrm{~g} \mathrm{~N} /$ plant in comparison with $\left(3.82\right.$ and $3.96 \mathrm{~m}^{3} /$ plant) with the nitrogen fertilizer at $120 \mathrm{~g} / \mathrm{plant}$ in both seasons, respectively. In generally, potassium fertilizer rate at $140 \mathrm{~g} \mathrm{~K} / \mathrm{plant}$ induce a positive significant effect on plant canopy volume in both seasons. Furthermore, the interaction between two factors gave high value of plant canopy volume. Generally, $160 \mathrm{~g} \mathrm{~N} /$ plant combined with $140 \mathrm{~g} \mathrm{~K} /$ plant surpassed other combination in this concern.

Table 4: Effect of nitrogen and potassium fertilization rates and their interactions on plant canopy volume $\left(\mathrm{m}^{3}\right)$ of El-shamia cactus pear plants (2018 and 2019 seasons).

\begin{tabular}{ccccccccc}
\hline Nitrogen & \multicolumn{4}{c}{$\mathbf{2 0 1 8}$} & \multicolumn{4}{c}{$\mathbf{2 0 1 9}$} \\
\cline { 2 - 9 } $\begin{array}{c}\text { rates } \\
\mathbf{( g )}\end{array}$ & $\mathbf{1 0 0}$ & $\mathbf{1 2 0}$ & $\mathbf{1 4 0}$ & Mean & $\mathbf{1 0 0}$ & $\mathbf{1 2 0}$ & $\mathbf{1 4 0}$ & Mean \\
\hline $\mathbf{1 2 0}$ & $3.36 \mathrm{i}$ & $3.73 \mathrm{~h}$ & $4.38 \mathrm{~g}$ & $3.82 \mathrm{C}$ & $3.48 \mathrm{i}$ & $3.86 \mathrm{~h}$ & $4.53 \mathrm{~g}$ & $3.96 \mathrm{C}$ \\
$\mathbf{1 4 0}$ & $5.15 \mathrm{f}$ & $5.75 \mathrm{e}$ & $6.35 \mathrm{~d}$ & $5.74 \mathrm{~B}$ & $5.33 \mathrm{f}$ & $5.96 \mathrm{e}$ & $6.56 \mathrm{~d}$ & $5.95 \mathrm{~B}$ \\
$\mathbf{1 6 0 g}$ & $7.18 \mathrm{c}$ & $7.66 \mathrm{~b}$ & $8.29 \mathrm{a}$ & $7.71 \mathrm{~A}$ & $7.45 \mathrm{c}$ & $7.94 \mathrm{~b}$ & $8.60 \mathrm{a}$ & $8.00 \mathrm{~A}$ \\
Mean & $5.23 \mathrm{C}$ & $5.71 \mathrm{~B}$ & $6.33 \mathrm{~A}$ & & $5.41 \mathrm{C}$ & $5.92 \mathrm{~B}$ & $6.56 \mathrm{~A}$ & \\
\hline
\end{tabular}

Means followed by the same letter (s) within each row, column or interaction are not significantly different at $5 \%$ level.

\section{Number of cladodes/plant}

Table, 5 indicates that $160 \mathrm{~g}$ nitrogen/plant produced higher number of cladodes/plant than 120 and $140 \mathrm{~g}$ nitrogen/plant in both seasons of study. Moreover, $140 \mathrm{~g}$ potassium/plant induced high positive effect on number of cladodes/plant followed by 120 and $100 \mathrm{~g}$ potassium/plant, respectively in both seasons. However, the interaction between nitrogen and potassium fertilization rate exerted high positive effect on number of cladodes/plant in both seasons. Generally, combinations of $160 \mathrm{~g}$ nitrogen/plant combined with $140 \mathrm{~g}$ potassium/plant showed superiority in this concern.

Table 5: Effect of nitrogen and potassium fertilization rates and their interactions on number of cladodes per plant of El-shamia cactus pear plants (2018 and 2019 seasons).

\begin{tabular}{ccccccccc}
\hline Nitrogen & \multicolumn{4}{c}{$\mathbf{2 0 1 8}$} \\
\cline { 2 - 8 } $\begin{array}{c}\text { rates } \\
(\mathbf{g})\end{array}$ & $\mathbf{1 0 0}$ & $\mathbf{1 2 0}$ & $\mathbf{1 4 0}$ & Mean & $\mathbf{1 0 0}$ & $\mathbf{1 2 0}$ & $\mathbf{1 4 0}$ & Mean \\
\cline { 2 - 8 } & $14.00 \mathrm{f}$ & $18.00 \mathrm{e}$ & $19.67 \mathrm{e}$ & $17.22 \mathrm{C}$ & $17.00 \mathrm{f}$ & $21.00 \mathrm{e}$ & $22.66 \mathrm{e}$ & $20.22 \mathrm{C}$ \\
$\mathbf{1 2 0}$ & $25.00 \mathrm{~d}$ & $27.66 \mathrm{~d}$ & $37.66 \mathrm{c}$ & $30.11 \mathrm{~B}$ & $30.00 \mathrm{~d}$ & $32.67 \mathrm{~d}$ & $42.66 \mathrm{c}$ & $35.11 \mathrm{~B}$ \\
$\mathbf{1 4 0}$ & $42.67 \mathrm{~b}$ & $44.66 \mathrm{ab}$ & $47.00 \mathrm{a}$ & $44.77 \mathrm{~A}$ & $47.67 \mathrm{~b}$ & $49.66 \mathrm{ab}$ & $52.00 \mathrm{a}$ & $49.77 \mathrm{~A}$ \\
$\mathbf{1 6 0}$ & $27.22 \mathrm{C}$ & $30.11 \mathrm{~B}$ & $34.77 \mathrm{~A}$ & & $31.55 \mathrm{C}$ & $34.44 \mathrm{~B}$ & $39.11 \mathrm{~A}$ & \\
Mean & &
\end{tabular}

Means followed by the same letter (s) within each row, column or interaction are not significantly different at $5 \%$ level.

\section{Cladodes length (cm)}

Table, 6 indicates that $160 \mathrm{~g}$ nitrogen/plant produced longer cladodes length than 140 and $120 \mathrm{~g}$ nitrogen/plant in both seasons, respectively. However, 140g potassium/plant gave higher value of cladodes length than 120 and 100g potassium/plant in both seasons, respectively. As for, interaction 
between nitrogen and potassium fertilization rate exerted that $160 \mathrm{~g}$ nitrogen/plant combined with 120 and/or $140 \mathrm{~g}$ potassium/plant had similar significant values of cladodes length and surpassed other tested combinations in this respect.

Table 6: Effect of nitrogen and potassium fertilization rates and their interactions on cladodes length (cm) of El-shamia cactus pear plants (2018 and 2019 seasons).

\begin{tabular}{|c|c|c|c|c|c|c|c|c|}
\hline \multirow{3}{*}{$\begin{array}{l}\text { Nitrogen } \\
\text { rates } \\
\text { (g) }\end{array}$} & \multicolumn{4}{|c|}{2018} & \multicolumn{4}{|c|}{2019} \\
\hline & \multicolumn{4}{|c|}{ Potassium rates (g) } & \multicolumn{4}{|c|}{ Potassium rates $(\mathrm{g})$} \\
\hline & 100 & 120 & 140 & Mean & 100 & 120 & 140 & Mean \\
\hline 120 & $31.33 \mathrm{~h}$ & $32.33 \mathrm{~g}$ & $34.33 \mathrm{f}$ & $32.66 \mathrm{C}$ & $33.43 \mathrm{~h}$ & $34.53 \mathrm{~g}$ & $36.63 \mathrm{f}$ & $34.86 \mathrm{C}$ \\
\hline 140 & $36.00 \mathrm{e}$ & $37.33 \mathrm{c}$ & $38.33 \mathrm{c}$ & $37.22 \mathrm{~B}$ & $38.40 \mathrm{e}$ & $39.83 \mathrm{~d}$ & $40.93 \mathrm{~b}$ & $39.72 \mathrm{~B}$ \\
\hline 160 & $40.00 \mathrm{~b}$ & $41.00 \mathrm{a}$ & $41.33 \mathrm{a}$ & $40.77 \mathrm{~A}$ & $42.70 \mathrm{~b}$ & $43.80 \mathrm{a}$ & $44.23 \mathrm{a}$ & $43.57 \mathrm{~A}$ \\
\hline Mean & $35.77 \mathrm{C}$ & $36.88 \mathrm{~B}$ & $38.00 \mathrm{~A}$ & & $38.17 \mathrm{C}$ & $39.38 \mathrm{~B}$ & $40.60 \mathrm{~A}$ & \\
\hline
\end{tabular}

Means followed by the same letter (s) within each row, column or interaction are not significantly different at $5 \%$ level.

\section{Cladodes width (cm)}

Table, 7 reveals that $160 \mathrm{~g}$ nitrogen/plant gave wider cladodes/plant than 120 and $140 \mathrm{~g}$ nitrogen/plant in both seasons. However, $120 \mathrm{~g}$ and $140 \mathrm{~g}$ potassium/plant gave similar and high positive effect on cladode width in both seasons. The interaction between two studied factors showed that, $160 \mathrm{~g}$ nitrogen/plant plus $120 \mathrm{~g}$ potassium/plant and $160 \mathrm{~g}$ nitrogen/plant plus $140 \mathrm{~g}$ potassium/plant gave similar and the highest significant values as well as surpassed other tested combinations in both seasons.

Table 7: Effect of nitrogen and potassium fertilization rates and their interactions on cladodes width (cm) of El-shamia cactus pear plants (2018 and 2019 seasons).

\begin{tabular}{|c|c|c|c|c|c|c|c|c|}
\hline \multirow{3}{*}{$\begin{array}{l}\text { Nitrogen } \\
\text { rates } \\
\text { (g) }\end{array}$} & \multicolumn{4}{|c|}{2018} & \multicolumn{4}{|c|}{2019} \\
\hline & \multicolumn{4}{|c|}{ Potassium rates(g) } & \multicolumn{4}{|c|}{ Potassium rates(g) } \\
\hline & 100 & 120 & 140 & Mean & 100 & 120 & 140 & Mean \\
\hline 120 & $16.33 \mathrm{~d}$ & $16.66 \mathrm{~cd}$ & $17.33 \mathrm{c}$ & $16.77 \mathrm{C}$ & $18.43 \mathrm{f}$ & $18.86 \mathrm{ef}$ & $19.63 \mathrm{de}$ & $18.97 \mathrm{C}$ \\
\hline 140 & $17.33 \mathrm{c}$ & $18.33 \mathrm{~b}$ & $18.33 \mathrm{~b}$ & $18.00 \mathrm{~B}$ & $19.73 \mathrm{~d}$ & 20.83.c & $20.93 \mathrm{bc}$ & $20.50 \mathrm{~B}$ \\
\hline 160 & $19.00 \mathrm{~b}$ & $20.33 \mathrm{a}$ & $20.66 \mathrm{a}$ & $20.00 \mathrm{~A}$ & $21.70 \mathrm{~b}$ & $23.13 \mathrm{a}$ & $23.56 \mathrm{a}$ & $22.80 \mathrm{~A}$ \\
\hline Mean & $17.55 \mathrm{~B}$ & $18.44 \mathrm{~A}$ & $18.77 \mathrm{~A}$ & & $19.95 \mathrm{~B}$ & $20.94 \mathrm{~A}$ & $21.37 \mathrm{~A}$ & \\
\hline
\end{tabular}

Means followed by the same letter (s) within each row, column or interaction are not significantly different at $5 \%$ level.

\section{Cladodes area $\left(\mathrm{cm}^{2}\right)$}

Table, 8 indicates that nitrogen fertilizer rates increased cladodes area in both seasons of study. Generally, nitrogen fertilizer at $160 \mathrm{~g} /$ plant proved to be the superior treatment in this concern. Moreover, potassium fertilizer rates increased cladodes area in both seasons of study. Shortly, $140 \mathrm{~g}$ $\mathrm{K} /$ plant showed superiority in this concern. However, the interaction between the two tested factors showed that nitrogen combined with potassium enhanced cladodes area in both seasons of study. Briefly, $160 \mathrm{~g} \mathrm{~N} /$ plant combined with $120 \mathrm{~g} \mathrm{~K} /$ plant and $160 \mathrm{~g} \mathrm{~N} /$ plant combined with $140 \mathrm{~g} \mathrm{~K} /$ plant proved to be the superior treatment in both seasons. Other combinations showed an intermediate values in this respect.

Table 8: Effect of nitrogen and potassium fertilization rates and their interactions on cladodes area $\left(\mathrm{cm}^{2}\right)$ of El-shamia cactus pear plants (2018 and 2019 seasons).

\begin{tabular}{ccccccccc}
\hline Nitrogen & \multicolumn{4}{c}{$\mathbf{2 0 1 8}$} \\
\cline { 2 - 9 } rates & \multicolumn{4}{c}{ Potassium rates $(\mathbf{g})$} & & \multicolumn{4}{c}{$\mathbf{2 0 1 9}$} \\
\cline { 2 - 9 } $\mathbf{( g )}$ & $\mathbf{1 0 0}$ & $\mathbf{1 2 0}$ & $\mathbf{1 4 0}$ & Mean & $\mathbf{1 0 0}$ & $\mathbf{1 2 0}$ & $\mathbf{1 4 0}$ & Mean \\
\hline $\mathbf{1 2 0}$ & $354.59 \mathrm{e}$ & $373.53 \mathrm{e}$ & $412.57 \mathrm{~d}$ & $380.23 \mathrm{C}$ & $427.01 \mathrm{e}$ & $451.59 \mathrm{e}$ & $498.58 \mathrm{~d}$ & $459.06 \mathrm{C}$ \\
$\mathbf{1 4 0}$ & $432.43 \mathrm{~d}$ & $474.47 \mathrm{c}$ & $487.18 \mathrm{c}$ & $464.70 \mathrm{~B}$ & $525.13 \mathrm{~d}$ & $575.25 \mathrm{c}$ & $593.97 \mathrm{c}$ & $564.78 \mathrm{~B}$ \\
$\mathbf{1 6 0}$ & $526.68 \mathrm{~b}$ & $577.96 \mathrm{a}$ & $592.05 \mathrm{a}$ & $565.56 \mathrm{~A}$ & $642.03 \mathrm{~b}$ & $702.41 \mathrm{a}$ & $722.48 \mathrm{a}$ & $689.01 \mathrm{~A}$ \\
Mean & $437.90 \mathrm{C}$ & $475.32 \mathrm{~B}$ & $497.27 \mathrm{~A}$ & & $531.42 \mathrm{C}$ & $576.41 \mathrm{~B}$ & $605.01 \mathrm{~A}$ & \\
\hline
\end{tabular}

Means followed by the same letter (s) within each row, column or interaction are not significantly different at $5 \%$ level. 
The improved effect of nitrogen fertilization rates on vegetative growth of cactus pear (plant height, plant canopy, number of cladodes/plant, cladode length, cladodes width and cladodes area) may be attributed to nitrogen is a necessary element for chlorophyll, protoplasm, protein and nucleic acid synthesis (Nijjar, 1985). Moreover, the nitrogen fertilization increased the availability and transport of nutrients, promoting greater absorption by plants, which resulted in higher growth (Novais and Mello, 2007). Nitrogen fertilizer as soil application induces greater root and shoot growth, higher metabolism and greater absorption (Cantarella and Nitrogênio, 2007). All of these led to more uptakes of nutrients and reflected on enhanced plant height, increased plant canopy, produced higher number of cladodes/plant, produced longer cladodes length, gave wider cladodes and improved cladodes area. The obtained results regarding the effect of nitrogen rates on plant growth go with line the findings of Silva et al., (1998) reported that nitrogen fertilization increased the total number of cladodes of cactus pear. Moreover, increasing applied of nitrogen from 0 to $160 \mathrm{~kg} / \mathrm{ha}$ increased the number of new cladodes and cladode area of cactus pear plants (Nobel, et al., 1987). Furthermore, Silva et al., (2016) mentioned that nitrogen fertilization at $200 \mathrm{~kg} \mathrm{ha}^{-1}$ increased plant height, number of cladodes per plant and cladode area index of cactus pear. On the other hand, Nitrogen fertilization gave the highest means for plant height $(63.5 \mathrm{~cm})$, plant width $(86.6 \mathrm{~cm})$ and number of cladodes $(13.9)$ against non-fertilized plants, which produced the lowest means: $44.8 \mathrm{~cm}, 56.3 \mathrm{~cm}$ and 7.70 , respectively of cactus pear (Neto et al., 2020). The enhancement effect of potassium rates on vegetative growth of cactus pear may be attributed to potassium is related to the synthesis of carbohydrates, sugars and starch storage and this stimulated the growth and improved utilization of water (Faquin, 1994). Also, this enhancement in leaf chlorophyll content could be attributed to the increase of macronutrients uptake, especially $\mathrm{K}, \mathrm{N}$ and $\mathrm{Mg}$ element, moreover, $\mathrm{N}$ and $\mathrm{Mg}$ nutrient are necessary for chlorophyll synthesis (Mengel and Kirkby, 1978). And that reflected of increased in plant height, plant canopy, cladodes number of plant, cladodes length, cladodes width and cladodes area. The obtained results of potassium rates regarding their positive effect on vegetative growth of cactus pear are in harmony with the findings of Silva et al., (2016) on cactus pear. The enhancement effect of interaction between nitrogen and potassium regarding their positive effect on vegetative growth may be attributed that fertilizations with NK stimulated the increase in plant height, number of cladodes and cladode area. Moreover, the NK fertilizations increased the availability and transport of nutrients, promoting greater absorption by plants, which resulted in higher growth (Novais \& Mello, 2007). The obtained results of interaction between nitrogen and potassium regarding their positive effect on vegetative growth are in harmony with the findings of Ramos et al., (2011) indicated that the number of cladodes was higher in plants under NPK fertilization as compared with those not fertilized. Silva et al., (2016) mentioned that plants fertilized with $\left(200 \mathrm{~N}-150 \mathrm{P}-100 \mathrm{~K} \mathrm{~kg} \mathrm{ha}{ }^{-1}\right)$ had greater height $92.86 \mathrm{~cm}$ against untreated plants $75.72 \mathrm{~cm}$ and higher number of cladodes (13.89) as compared with the treatments without fertilizer (11.33). Also, the treatments with NPK showed greater cladode area index compared with untreated plants of cactus pear.

\subsection{Cladodes minerals content}

\section{Nitrogen (\%)}

Table, 9 demonstrates that increasing in nitrogen rates led in increasing nitrogen content of cladodes in both season. Generally, $160 \mathrm{~g} \mathrm{~N} /$ plant proved to be the superior rate in this concern. In general, potassium gave higher values of cladode nitrogen content in both seasons. Moreover, 140g $\mathrm{K} /$ plant gave the highest nitrogen content of cladodes in both seasons. Furthermore, interaction between nitrogen and potassium rates showed that in the first season, $160 \mathrm{~g} \mathrm{~N} /$ plant plus $140 \mathrm{~g} \mathrm{~K} / \mathrm{plant}$ and in the second season, $160 \mathrm{~g} \mathrm{~N} /$ plant plus 120 and/or $140 \mathrm{~g} \mathrm{~K} /$ plant gave the highest values of cladodes nitrogen content. Other tested combinations gave an intermediate values in this concern. 
Table 9: Effect of nitrogen and potassium fertilization rates and their interactions on cladodes nitrogen content (\%) of El-shamia cactus pear plants (2018 and 2019 seasons).

\begin{tabular}{ccccccccc}
\hline Nitrogen & \multicolumn{4}{c}{$\mathbf{2 0 1 8}$} \\
\cline { 2 - 8 } rate & \multicolumn{3}{c}{ Potassium rates $(\mathbf{g})$} & \multicolumn{1}{c}{ Potassium rates(g) } \\
\cline { 2 - 9 } & $\mathbf{1 0 0}$ & $\mathbf{1 2 0}$ & $\mathbf{1 4 0}$ & Mean & $\mathbf{1 0 0}$ & $\mathbf{1 2 0}$ & $\mathbf{1 4 0}$ & Mean \\
\hline $\mathbf{1 2 0}$ & $0.53 \mathrm{~h}$ & $0.59 \mathrm{~g}$ & $0.67 \mathrm{f}$ & $0.59 \mathrm{C}$ & $0.64 \mathrm{~g}$ & $0.70 \mathrm{f}$ & $0.79 \mathrm{e}$ & $0.71 \mathrm{C}$ \\
$\mathbf{1 4 0}$ & $0.70 \mathrm{e}$ & $0.74 \mathrm{~d}$ & $0.76 \mathrm{c}$ & $0.73 \mathrm{~B}$ & $0.82 \mathrm{~d}$ & $0.86 \mathrm{c}$ & $0.89 \mathrm{~b}$ & $0.85 \mathrm{~B}$ \\
$\mathbf{1 6 0}$ & $0.77 \mathrm{bc}$ & $0.78 \mathrm{ab}$ & $0.79 \mathrm{a}$ & $0.78 \mathrm{~A}$ & $0.90 \mathrm{~b}$ & $0.93 \mathrm{a}$ & $0.94 \mathrm{a}$ & $0.92 \mathrm{~A}$ \\
Mean & $0.66 \mathrm{C}$ & $0.70 \mathrm{~B}$ & $0.74 \mathrm{~A}$ & & $0.78 \mathrm{C}$ & $0.83 \mathrm{~B}$ & $0.87 \mathrm{~A}$ & \\
\hline
\end{tabular}

Means followed by the same letter (s) within each row, column or interaction are not significantly different at $5 \%$ level.

\section{Phosphorus (\%)}

Data in table (10) indicate that $160 \mathrm{~g} \mathrm{~N} /$ plant had higher values of cladodes phosphorus content $(0.25$ and $0.29 \%)$ against $(0.14$ and $0.15 \%)$ for $120 \mathrm{~g} \mathrm{~N} / \mathrm{plant}$ in both seasons, respectively. However, potassium fertilization enhanced phosphorus content of cladodes than two concentrations in both season. While, $140 \mathrm{~g} \mathrm{~K} / \mathrm{plant}$ gave the highest values of cladode phosphorus content in both seasons. Furthermore, the interaction between rates of nitrogen and potassium rates showed that $160 \mathrm{~g} \mathrm{~N} / \mathrm{plant}$ combined with $140 \mathrm{~g} \mathrm{~K} /$ plant and $160 \mathrm{~g} \mathrm{~N} /$ plant combined with $120 \mathrm{~g} \mathrm{~K} /$ plant gave similar and high phosphorus content of cladodes in both seasons.

Table 10: Effect of nitrogen and potassium fertilization rates and their interactions on cladodes phosphours content (\%) of El-shamia cactus pear plants (2018 and 2019 seasons).

\begin{tabular}{ccccccccc}
\hline Nitrogen & \multicolumn{4}{c}{$\mathbf{2 0 1 8}$} & \multicolumn{4}{c}{$\mathbf{2 0 1 9}$} \\
\cline { 2 - 9 } \begin{tabular}{c} 
rates \\
\cline { 2 - 8 }$(\mathbf{g})$
\end{tabular} & $\mathbf{1 0 0}$ & $\mathbf{1 2 0}$ & $\mathbf{1 4 0}$ & Mean & $\mathbf{1 0 0}$ & $\mathbf{1 2 0}$ & $\mathbf{1 4 0}$ & Mean \\
\hline $\mathbf{1 2 0}$ & $0.11 \mathrm{~h}$ & $0.15 \mathrm{~g}$ & $0.17 \mathrm{f}$ & $0.14 \mathrm{C}$ & $0.12 \mathrm{~h}$ & $0.16 \mathrm{~g}$ & $0.19 \mathrm{f}$ & $0.15 \mathrm{C}$ \\
$\mathbf{1 4 0}$ & $0.20 \mathrm{e}$ & $0.22 \mathrm{~d}$ & $0.24 \mathrm{c}$ & $0.22 \mathrm{~B}$ & $0.22 \mathrm{e}$ & $0.24 \mathrm{~d}$ & $0.26 \mathrm{c}$ & $0.24 \mathrm{~B}$ \\
$\mathbf{1 6 0}$ & $0.25 \mathrm{~b}$ & $0.26 \mathrm{a}$ & $0.26 \mathrm{a}$ & $0.25 \mathrm{~A}$ & $0.28 \mathrm{~b}$ & $0.30 \mathrm{a}$ & $0.30 \mathrm{a}$ & $0.29 \mathrm{~A}$ \\
Mean & $0.18 \mathrm{C}$ & $0.21 \mathrm{~B}$ & $0.22 \mathrm{~A}$ & & $0.20 \mathrm{C}$ & $0.23 \mathrm{~B}$ & $0.25 \mathrm{~A}$ & \\
\hline
\end{tabular}

Means followed by the same letter (s) within each row, column or interaction are not significantly different at $5 \%$ level.

\section{Potassium (\%)}

Table, 11 illustrates that nitrogen rates had no significant effect on potassium content of cladodes in the first season. While, $160 \mathrm{~g} \mathrm{~N} /$ plant gave the highest potassium content of cladodes than two rates of nitrogen in the second season. However, potassium fertilization had no significant effect on potassium content of cladodes in the first season. Moreover, $140 \mathrm{~g} \mathrm{~K} / \mathrm{plant}$ proved to be the superior treatment in the second season. Furthermore, the interaction between nitrogen and potassium rates showed that $160 \mathrm{~g} \mathrm{~N} /$ plant combined with $140 \mathrm{~g} \mathrm{~K} /$ plant proved to be the best combinations in this concern. Other combination gave an intermediate values in this respect.

Table 11: Effect of nitrogen and potassium fertilization rates and their interactions on cladodes potassium content (\%) of El-shamia cactus pear plants (2018 and 2019 seasons).

\begin{tabular}{|c|c|c|c|c|c|c|c|c|}
\hline \multirow{3}{*}{$\begin{array}{l}\text { Nitrogen } \\
\text { rates } \\
\text { (g) }\end{array}$} & \multicolumn{4}{|c|}{2018} & \multicolumn{4}{|c|}{2019} \\
\hline & \multicolumn{4}{|c|}{ Potassium rates(g) } & \multicolumn{4}{|c|}{ Potassium rates(g) } \\
\hline & 100 & 120 & 140 & Mean & 100 & 120 & $140 \mathrm{~g}$ & Mean \\
\hline 120 & $2.50 \mathrm{~b}$ & $3.51 \mathrm{ab}$ & $2.61 \mathrm{~b}$ & $2.87 \mathrm{~A}$ & $2.61 \mathrm{f}$ & $3.02 \mathrm{e}$ & $3.05 \mathrm{~d}$ & $2.89 \mathrm{C}$ \\
\hline 140 & $3.06 \mathrm{ab}$ & $3.07 \mathrm{ab}$ & $3.08 \mathrm{ab}$ & $3.07 \mathrm{~A}$ & $3.06 \mathrm{~d}$ & $3.07 \mathrm{~d}$ & $3.08 \mathrm{~d}$ & $3.07 \mathrm{~B}$ \\
\hline 160 & $3.12 \mathrm{ab}$ & $3.26 \mathrm{ab}$ & $3.75 \mathrm{a}$ & $3.37 \mathrm{~A}$ & $3.71 \mathrm{c}$ & $3.94 \mathrm{~b}$ & $4.11 \mathrm{a}$ & $3.92 \mathrm{~A}$ \\
\hline Mean & $2.89 \mathrm{~A}$ & $3.14 \mathrm{~A}$ & $3.28 \mathrm{~A}$ & & $3.12 \mathrm{C}$ & $3.34 \mathrm{~B}$ & $3.41 \mathrm{~A}$ & \\
\hline
\end{tabular}

Means followed by the same letter (s) within each row, column or interaction are not significantly different at $5 \%$ level.

\section{Calcium (\%)}

Table, 12 indicates that $160 \mathrm{~g} \mathrm{~N} /$ plant enhanced calcium content of cladodes than two rates in both season. Moreover, potassium fertilization at $140 \mathrm{~g} /$ plant enhanced calcium content of cladodes 
than two rates in both season. Whereas, the interaction between nitrogen and potassium rates indicated that $160 \mathrm{~g} \mathrm{~N} /$ plant combined with $140 \mathrm{~g} \mathrm{~K} /$ plant exerted higher positive effect on calcium content of cladodes and proved to be the superiority combination in both seasons. Furthermore, other combinations gave an intermediate values in this respect.

Table 12: Effect of nitrogen and potassium fertilization rates and their interactions on cladodes calcium content (\%) of El-shamia cactus pear plants (2018 and 2019 seasons).

\begin{tabular}{ccccccccc}
\hline Nitrogen & \multicolumn{4}{c}{$\mathbf{2 0 1 8}$} & \multicolumn{4}{c}{$\mathbf{2 0 1 9}$} \\
\cline { 2 - 9 } rates & \multicolumn{3}{c}{ Potassium rates(g) } & & \multicolumn{4}{c}{ Potassium rates(g) } \\
\cline { 2 - 8 }$(\mathbf{g})$ & $\mathbf{1 0 0}$ & $\mathbf{1 2 0}$ & $\mathbf{1 4 0}$ & Mean & $\mathbf{1 0 0}$ & $\mathbf{1 2 0}$ & $\mathbf{1 4 0}$ & Mean \\
\hline $\mathbf{1 2 0}$ & $5.23 \mathrm{~h}$ & $5.27 \mathrm{gh}$ & $5.31 \mathrm{~g}$ & $5.27 \mathrm{C}$ & $6.35 \mathrm{~h}$ & $6.41 \mathrm{~g}$ & $6.46 \mathrm{~g}$ & $6.40 \mathrm{C}$ \\
$\mathbf{1 4 0}$ & $5.40 \mathrm{f}$ & $5.52 \mathrm{e}$ & $5.61 \mathrm{~d}$ & $5.51 \mathrm{~B}$ & $6.74 \mathrm{f}$ & $6.86 \mathrm{e}$ & $6.95 \mathrm{~d}$ & $6.85 \mathrm{~B}$ \\
$\mathbf{1 6 0}$ & $5.82 \mathrm{c}$ & $5.91 \mathrm{~b}$ & $6.08 \mathrm{a}$ & $5.93 \mathrm{~A}$ & $7.16 \mathrm{c}$ & $7.26 \mathrm{~b}$ & $7.43 \mathrm{a}$ & $7.28 \mathrm{~A}$ \\
Mean & $5.48 \mathrm{C}$ & $5.56 \mathrm{~B}$ & $5.66 \mathrm{~A}$ & & $6.94 \mathrm{C}$ & $6.84 \mathrm{~B}$ & $6.75 \mathrm{~A}$ & \\
\hline
\end{tabular}

Means followed by the same letter (s) within each row, column or interaction are not significantly different at $5 \%$ level.

\section{Magnesium (\%)}

Table, 13 reveals that increasing in nitrogen rates led in increasing magnesium content of cladodes in both seasons. However, $160 \mathrm{~g} \mathrm{~N} /$ plant proved to be the superior rate in this concern. Moreover, potassium gave higher values of cladode magnesium content in both seasons. Moreover, $140 \mathrm{~g} \mathrm{~K} /$ plant gave the highest magnesium content of cladodes in both seasons. Furthermore, the interaction between nitrogen and potassium rate exerted high positive effect on magnesium content of cladodes in both season. Generally, $160 \mathrm{~g} \mathrm{~N} /$ plant combined with $140 \mathrm{~g} \mathrm{~K} /$ plant proved to be the best interaction in this concern.

Table 13: Effect of nitrogen and potassium fertilization rates and their interactions on cladodes magnesium content (\%) of El-shamia cactus pear plants (2018 and 2019 seasons).

\begin{tabular}{ccccccccc}
\hline Nitrogen & \multicolumn{4}{c}{$\mathbf{2 0 1 8}$} & \multicolumn{4}{c}{$\mathbf{2 0 1 9}$} \\
\cline { 2 - 9 } rates & \multicolumn{3}{c}{ Potassium rates(g) } & & \multicolumn{4}{c}{ Potassium rates(g) } \\
\cline { 2 - 8 }$(\mathbf{g})$ & $\mathbf{1 0 0}$ & $\mathbf{1 2 0}$ & $\mathbf{1 4 0}$ & Mean & $\mathbf{1 0 0}$ & $\mathbf{1 2 0}$ & $\mathbf{1 4 0}$ & Mean \\
\hline $\mathbf{1 2 0}$ & $0.83 \mathrm{~g}$ & $0.84 \mathrm{f}$ & $0.86 \mathrm{e}$ & $0.84 \mathrm{C}$ & $0.88 \mathrm{~h}$ & $0.89 \mathrm{~g}$ & $0.91 \mathrm{f}$ & $0.89 \mathrm{C}$ \\
$\mathbf{1 4 0}$ & $0.87 \mathrm{~d}$ & $0.89 \mathrm{c}$ & $0.90 \mathrm{bc}$ & $0.89 \mathrm{~B}$ & $0.93 \mathrm{e}$ & $0.96 \mathrm{~d}$ & $0.98 \mathrm{c}$ & $0.96 \mathrm{~B}$ \\
$\mathbf{1 6 0}$ & $0.91 \mathrm{~b}$ & $0.91 \mathrm{~b}$ & $0.93 \mathrm{a}$ & $0.91 \mathrm{~A}$ & $1.00 \mathrm{~b}$ & $1.00 \mathrm{~b}$ & $1.02 \mathrm{a}$ & $1.01 \mathrm{~A}$ \\
Mean & $0.87 \mathrm{C}$ & $0.88 \mathrm{~B}$ & $0.90 \mathrm{~A}$ & & $0.94 \mathrm{C}$ & $0.95 \mathrm{~B}$ & $0.97 \mathrm{~A}$ & \\
\hline
\end{tabular}

Means followed by the same letter (s) within each row, column or interaction are not significantly different at $5 \%$ level.

\section{Iron (ppm)}

Table, 14 indicates that 140 and $160 \mathrm{~g} \mathrm{~N} /$ plant enhanced iron content of cladodes than $120 \mathrm{~g}$ $\mathrm{N} /$ plant in both season. Moreover, $140 \mathrm{~g} \mathrm{~K} /$ plant gave the highest iron content of cladodes than two rates in both seasons. Furthermore, the interaction between nitrogen and potassium rates indicated that in the first season, $160 \mathrm{~g} \mathrm{~N} /$ plant combined with 100 and/or 120 and/or $140 \mathrm{~g} \mathrm{~K} /$ plant also; $140 \mathrm{~g}$ $\mathrm{N} /$ plant combined with 120 and/or $140 \mathrm{~g} \mathrm{~K} /$ plant had similar and higher values of cladode iron content and proved to be the best combinations in this concern. While in the second seasons, $160 \mathrm{~g} \mathrm{~N} / \mathrm{plant}$ combined with $140 \mathrm{~g} \mathrm{~K} /$ plant proved to be the best interaction in this concern. Other combination gave an intermediate values in this respect.

Table 14: Effect of nitrogen and potassium fertilization rates and their interactions on cladodes iron content (ppm) of El-shamia cactus pear plants (2018 and 2019 seasons).

\begin{tabular}{ccccccccc}
\hline Nitrogen & \multicolumn{4}{c}{$\mathbf{2 0 1 8}$} \\
\cline { 2 - 9 } rates & \multicolumn{4}{c}{ Potassium rates(g) } & \multicolumn{4}{c}{$\mathbf{2 0 1 9}$} \\
\cline { 2 - 8 } (g) & $\mathbf{1 0 0}$ & $\mathbf{1 2 0}$ & $\mathbf{1 4 0}$ & Mean & $\mathbf{1 0 0}$ & $\mathbf{1 2 0}$ & $\mathbf{1 4 0}$ & Mean \\
\hline $\mathbf{1 2 0}$ & $42.01 \mathrm{c}$ & $43.20 \mathrm{bc}$ & $44.96 \mathrm{ab}$ & $43.39 \mathrm{~B}$ & $43.16 \mathrm{~d}$ & $44.35 \mathrm{bc}$ & $46.11 \mathrm{bc}$ & $44.54 \mathrm{~B}$ \\
$\mathbf{1 4 0}$ & $45.67 \mathrm{ab}$ & $46.25 \mathrm{a}$ & $46.99 \mathrm{a}$ & $46.30 \mathrm{~A}$ & $46.82 \mathrm{abc}$ & $47.60 \mathrm{ab}$ & $48.45 \mathrm{ab}$ & $47.62 \mathrm{~A}$ \\
$\mathbf{1 6 0}$ & $47.52 \mathrm{a}$ & $47.70 \mathrm{a}$ & $47.90 \mathrm{a}$ & $47.70 \mathrm{~A}$ & $49.09 \mathrm{ab}$ & $49.15 \mathrm{ab}$ & $49.20 \mathrm{a}$ & $49.14 \mathrm{~A}$ \\
Mean & $45.06 \mathrm{~B}$ & $45.71 \mathrm{AB}$ & $46.61 \mathrm{~A}$ & & $46.39 \mathrm{~B}$ & $47.01 \mathrm{AB}$ & $47.90 \mathrm{~A}$ & \\
\hline
\end{tabular}

Means followed by the same letter (s) within each row, column or interaction are not significantly different at $5 \%$ level. 


\section{Manganese (ppm)}

Table, 15 indicates that nitrogen fertilization increased manganese content of cladodes in both seasons. Generally, $160 \mathrm{~g} \mathrm{~N}$ /plant proved to be the superior treatment in this concern. Moreover, potassium rates enhanced manganese content of cladodes in both seasons. However, $140 \mathrm{~g} \mathrm{~K} / \mathrm{plant}$ proved to be the superior treatment in this respect. The interaction between two factors showed that nitrogen combined with potassium succeeded in increasing manganese content of cladodes in both seasons. Generally, $160 \mathrm{~g} \mathrm{~N} /$ plant combined with $140 \mathrm{~g} \mathrm{~K} /$ plant surpassed other combination in this sphere in both seasons.

Table 15: Effect of nitrogen and potassium fertilization rates and their interactions on cladodes manganese content (ppm) of El-shamia cactus pear plants (2018 and 2019 seasons).

\begin{tabular}{|c|c|c|c|c|c|c|c|c|}
\hline \multirow{3}{*}{$\begin{array}{c}\text { Nitrogen } \\
\text { rates } \\
\text { (g) }\end{array}$} & \multicolumn{4}{|c|}{2018} & \multicolumn{4}{|c|}{2019} \\
\hline & \multicolumn{4}{|c|}{ Potassium rates(g) } & \multicolumn{4}{|c|}{ Potassium rates(g) } \\
\hline & 100 & 120 & 140 & Mean & 100 & 120 & 140 & Mean \\
\hline 120 & $515.20 \mathrm{i}$ & $560.57 \mathrm{~h}$ & $580.53 \mathrm{~g}$ & $552.10 \mathrm{C}$ & $516.35 \mathrm{i}$ & $561.72 \mathrm{~h}$ & $581.68 \mathrm{~g}$ & $553.25 \mathrm{C}$ \\
\hline 140 & $630.78 \mathrm{f}$ & $690.61 \mathrm{e}$ & $740.12 \mathrm{~d}$ & $687.17 \mathrm{~B}$ & $631.93 \mathrm{f}$ & $691.96 \mathrm{e}$ & $741.58 \mathrm{~d}$ & $688.49 \mathrm{~B}$ \\
\hline 160 & $780.54 \mathrm{c}$ & $790.15 \mathrm{~b}$ & $810.45 \mathrm{a}$ & $793.71 \mathrm{~A}$ & $782.22 \mathrm{c}$ & $791.54 \mathrm{~b}$ & $811.70 \mathrm{a}$ & $795.15 \mathrm{~A}$ \\
\hline Mean & $462.21 \mathrm{C}$ & $680.32 \mathrm{~B}$ & $710.36 \mathrm{~A}$ & & $643.50 \mathrm{C}$ & $681.74 \mathrm{~B}$ & $711.65 \mathrm{~A}$ & \\
\hline
\end{tabular}

Means followed by the same letter (s) within each row, column or interaction are not significantly different at $5 \%$ level.

\section{Zinc (ppm)}

Table, 16 illustrates nitrogen rates increased zinc content of cladodes both seasons. Generally, $160 \mathrm{~g} \mathrm{~N} /$ plant showed to be the best treatment in this concern. Moreover, potassium rates had no significant effect on zinc content of cladodes in both seasons. The interaction between the two tested factors indicated that nitrogen combined with potassium succeeded in increasing zinc content of cladodes in both seasons. Shortly, in the first season, $160 \mathrm{~g} \mathrm{~N} /$ plant combined with $140 \mathrm{~g} \mathrm{~K} /$ plant and in the second season, $160 \mathrm{~g} \mathrm{~N} /$ plant combined with $120 \mathrm{~g}$ and/or $140 \mathrm{~g} \mathrm{~K} /$ plant proved to be the most efficient combinations in this concern.

Table 16: Effect of nitrogen and potassium fertilization rates and their interactions on cladodes zinc content (ppm) of El-shamia cactus pear plants (2018 and 2019 seasons).

\begin{tabular}{ccccccccc}
\hline Nitrogen & \multicolumn{4}{c}{$\mathbf{2 0 1 8}$} & \multicolumn{4}{c}{$\mathbf{2 0 1 9}$} \\
\cline { 2 - 9 } rates & \multicolumn{4}{c}{ Potassium rates(g) } & \multicolumn{10}{c}{ Potassium rates(g) } \\
\cline { 2 - 9 }$(\mathbf{1 4 0}$ & $\mathbf{1 0 0}$ & $\mathbf{1 2 0}$ & $\mathbf{1 4 0}$ & Mean & $\mathbf{1 0 0}$ & $\mathbf{1 2 0}$ & $\mathbf{1 4 0}$ & Mean \\
\hline $\mathbf{1 2 0}$ & $16.87 \mathrm{e}$ & $17.56 \mathrm{de}$ & $18.15 \mathrm{cde}$ & $17.54 \mathrm{C}$ & $17.53 \mathrm{~d}$ & $18.22 \mathrm{~cd}$ & $18.88 \mathrm{bcd}$ & $18.12 \mathrm{C}$ \\
$\mathbf{1 4 0}$ & $18.21 \mathrm{cde}$ & $18.60 \mathrm{bcd}$ & $18.96 \mathrm{abcd}$ & $18.57 \mathrm{~B}$ & $19.28 \mathrm{abc}$ & $19.54 \mathrm{abc}$ & $18.69 \mathrm{bcd}$ & $19.17 \mathrm{~B}$ \\
$\mathbf{1 6 0}$ & $19.25 \mathrm{abc}$ & $20.01 \mathrm{ab}$ & $20.35 \mathrm{a}$ & $19.87 \mathrm{~A}$ & $19.79 \mathrm{ab}$ & $20.43 \mathrm{a}$ & $20.77 \mathrm{a}$ & $20.33 \mathrm{~A}$ \\
Mean & $18.24 \mathrm{~A}$ & $18.84 \mathrm{~A}$ & $18.90 \mathrm{~A}$ & & $18.86 \mathrm{~A}$ & $19.39 \mathrm{~A}$ & $19.44 \mathrm{~A}$ & \\
\hline
\end{tabular}

Means followed by the same letter (s) within each row, column or interaction are not significantly different at 5\% level.

\section{Copper (ppm)}

Table, 17 indicates that nitrogen rates produced higher positive effect on copper content of cladodes in both seasons of study. Briefly, nitrogen at $160 \mathrm{~g} \mathrm{~N} /$ plant showed superiority in both season. Moreover, potassium rates gave high positive effect on copper content of cladodes in both seasons. Moreover, $140 \mathrm{~g} \mathrm{~N} /$ plant gave high positive effect on copper content of cladodes both seasons. On the other hand, the interaction between the two tested factors produced a pronounced positive effect on copper content of cladodes both seasons of study. Briefly, 160g N/plant combined with $140 \mathrm{~g} \mathrm{~K} /$ plant proved to be the superior combination in both seasons in this respect. 
Table 17: Effect of nitrogen and potassium fertilization rates and their interactions on cladodes copper content (ppm) of El-shamia cactus pear plants (2018 and 2019 seasons).

\begin{tabular}{|c|c|c|c|c|c|c|c|c|}
\hline \multirow{3}{*}{$\begin{array}{l}\text { Nitrogen } \\
\text { rates } \\
\text { (g) }\end{array}$} & \multicolumn{4}{|c|}{2018} & \multicolumn{4}{|c|}{2019} \\
\hline & \multicolumn{4}{|c|}{ Potassium rates(g) } & \multicolumn{4}{|c|}{ Potassium rates(g) } \\
\hline & 100 & 120 & 140 & Mean & 100 & 120 & 140 & Mean \\
\hline 120 & $14.83 \mathrm{f}$ & $15.63 \mathrm{f}$ & $17.48 \mathrm{e}$ & $15.98 \mathrm{C}$ & $15.95 \mathrm{f}$ & $16.77 \mathrm{f}$ & $18.63 \mathrm{e}$ & $17.12 \mathrm{C}$ \\
\hline 140 & $17.68 \mathrm{de}$ & 18.15 de & $18.67 \mathrm{~cd}$ & $18.16 \mathrm{~B}$ & $19.02 \mathrm{de}$ & $19.49 \mathrm{de}$ & $20.01 \mathrm{~cd}$ & $19.51 \mathrm{~B}$ \\
\hline 160 & $19.35 \mathrm{bc}$ & $20.12 \mathrm{~b}$ & $22.91 \mathrm{a}$ & $20.79 \mathrm{~A}$ & $20.69 \mathrm{bc}$ & $21.47 \mathrm{~b}$ & $24.26 \mathrm{a}$ & $22.14 \mathrm{~A}$ \\
\hline Mean & $17.28 \mathrm{C}$ & $17.96 \mathrm{~B}$ & $19.68 \mathrm{~A}$ & & $18.55 \mathrm{C}$ & $19.24 \mathrm{~B}$ & $20.97 \mathrm{~A}$ & \\
\hline
\end{tabular}

Means followed by the same letter (s) within each row, column or interaction are not significantly different at $5 \%$ level.

\section{Boron (ppm)}

Table, 18 illustrates that nitrogen rates gave high positive effect on boron content of cladodes in both seasons of study. Generally, $160 \mathrm{~g} \mathrm{~N} /$ plant proved surpassed other rates in this respect Moreover, potassium rates produced positive effect on boron content of cladodes in both seasons. Shortly, $140 \mathrm{~g}$ $\mathrm{N} /$ plant showed to be the superior treatment in this respect. The interaction between the two tested factors illustrated that nitrogen combined with potassium succeeded in increasing boron content of cladodes in both seasons. Generally, $160 \mathrm{~g} \mathrm{~N} /$ plant combined with $140 \mathrm{~g} \mathrm{~K} / \mathrm{plant}$ surpassed other combinations in both seasons. Other combinations showed an intermediate values in this respect.

Table 18: Effect of nitrogen and potassium fertilization rates and their interactions on cladodes boron content (ppm) of El-shamia cactus pear plants (2018 and 2019 seasons).

\begin{tabular}{ccccccccc}
\hline & \multicolumn{4}{c}{$\mathbf{2 0 1 8}$} & \multicolumn{3}{c}{$\mathbf{2 0 1 9}$} \\
\cline { 2 - 8 } $\begin{array}{c}\text { Nitrogen } \\
\text { rates }\end{array}$ & \multicolumn{3}{c}{ Potassium rates $(\mathbf{g})$} & & \multicolumn{3}{c}{ Potassium rates(g) } \\
\cline { 2 - 8 }$(\mathbf{g})$ & $\mathbf{1 0 0}$ & $\mathbf{1 2 0}$ & $\mathbf{1 4 0}$ & Mean & $\mathbf{1 0 0}$ & $\mathbf{1 2 0}$ & $\mathbf{1 4 0}$ & Mean \\
\hline $\mathbf{1 2 0}$ & $62.35 \mathrm{~h}$ & $64.36 \mathrm{~g}$ & $66.87 \mathrm{f}$ & $64.52 \mathrm{C}$ & $63.47 \mathrm{~h}$ & $65.50 \mathrm{~g}$ & $68.02 \mathrm{f}$ & $65.66 \mathrm{C}$ \\
$\mathbf{1 4 0}$ & $70.30 \mathrm{e}$ & $73.16 \mathrm{~d}$ & $75.11 \mathrm{c}$ & $72.86 \mathrm{~B}$ & $71.64 \mathrm{e}$ & $74.50 \mathrm{~d}$ & $76.45 \mathrm{c}$ & $74.20 \mathrm{~B}$ \\
$\mathbf{1 6 0}$ & $78.68 \mathrm{~b}$ & $79.15 \mathrm{~b}$ & $80.20 \mathrm{a}$ & $79.34 \mathrm{~A}$ & $80.02 \mathrm{~b}$ & $80.50 \mathrm{~b}$ & $81.55 \mathrm{a}$ & $80.69 \mathrm{~A}$ \\
Mean & $70.44 \mathrm{C}$ & $72.22 \mathrm{~B}$ & $74.06 \mathrm{~A}$ & & $71.71 \mathrm{C}$ & $73.50 \mathrm{~B}$ & $75.34 \mathrm{~A}$ & \\
\hline
\end{tabular}

Means followed by the same letter (s) within each row, column or interaction are not significantly different at $5 \%$ level.

The obtained results of nitrogen and potassium fertilization as well as their interaction regarding its positive effect on cladodes nutreints content are in harmony with the findings Claassens and Wessels (1997) concluded that cactus pear plants fertilized with nitrogen at 30 and $60 \mathrm{~kg} \mathrm{ha}^{-1}$ year $^{-1}$ gave cladode nitrogen content of $0.96 \%$ and cladode potassium content of $1.5 \%$. Moreover, Silva et al., (2012) reported that cactus pear plants fertilized with NPK increment cladodes N, P, S and $\mathrm{Mn}$ contents and improve the nutritional value. However, Dubeux et al., (2006) found that nitrogen fertilization increased $\mathrm{N}$ concentration of cladodes of cactus pear. On the other hand, cladodes nitrogen concentration increased linearly with an increase of nitrogen fertilization from 0 to $600 \mathrm{~kg} \mathrm{~N} \mathrm{ha}^{-1}$ year $^{-1}$ of cactus pear (Souza et al., 2017). Furthermore, cactus pear plants fertilized with $200 \mathrm{~N}-150 \mathrm{P}-100 \mathrm{~K} \mathrm{~kg} \mathrm{ha}^{-1}$ year $^{-1}$ improved cladodes nitrogen, phosphorus and sulphur contents as compared with unfertilized control and this increased in cladodes nutrients content can explained that nutrients are availability in the soil (Silva et al., 2016).

\section{Conclusion}

Shortly, the results showed that increasing in nitrogen rates and potassium rates led to enhanced vegetative growth and cladodes nutrients content. Besides, the increment in nitrogen combined with potassium gave an increased the plant growth and cladodes nutrients content of cactus pear. Fertilization with nitrogen at $160 \mathrm{~g} /$ plant increased plant height, plant canopy volume, number of cladodes per plant, cladode length, cladodes width and cladodes $\mathrm{N}, \mathrm{P}, \mathrm{Ca}, \mathrm{Mg}, \mathrm{Mn}, \mathrm{Zn}, \mathrm{Cu}$ and $\mathrm{B}$ content. Nitrogen rates had no significant effect on cladodes $\mathrm{K}$ content in first season and nitrogen at 160 and or 140 gave similar and high values of cladodes Fe content in both seasons. Fertilization potassium at $140 \mathrm{~g}$ /plant improved vegetative growth and cladodes $\mathrm{N}, \mathrm{P}, \mathrm{K}, \mathrm{Ca}, \mathrm{Mg}, \mathrm{Fe}, \mathrm{Mn}, \mathrm{Cu}$ and 
B content. However, it had no significant effect on cladodes $\mathrm{K}$ content in first season and cladodes $\mathrm{Zn}$ content in two seasons. Fertilization with nitrogen at $160 \mathrm{~g} / \mathrm{plant}$ combined with potassium at $140 \mathrm{~g} / \mathrm{plant}$ gave the highest positive effect on plant height, plant canopy volume, number of cladodes per plant, cladode length and cladodes $\mathrm{N}, \mathrm{P}, \mathrm{Ca}, \mathrm{Mg}, \mathrm{Mn}, \mathrm{Cu}$ and $\mathrm{B}$ content. The interaction between nitrogen rates and potassium rates indicated that $160 \mathrm{~g} \mathrm{~N} / \mathrm{plant}$ combined with 120 and/or $140 \mathrm{~g}$ $\mathrm{K} /$ plant also; $140 \mathrm{~g} \mathrm{~N} /$ plant combined with 120 and/or $140 \mathrm{~g} \mathrm{~K} /$ plant had similar and higher values of cladode iron content in first season. Finally, it is preferable to apply nitrogen fertilizer at $160 \mathrm{~g} / \mathrm{plant}$ combined with potassium at $140 \mathrm{~g} /$ plant to enhance growth, cladodes nutrients content of El-shamia cactus pear plants.

\section{References}

Arba, M., A. Falisse, R. Choukr-Allah, and M. Sindic, 2017. Effects of nitrogen and phosphorus fertilization on fruit yield and quality of cactus pear Opuntia ficus-indica (L.) Mill. Fruits, 72(4):212-220. https://doi.org/10.17660/th2017/72.4.3

Blanco-Macías, F., R. Magallanes-Quintanar, R.E. Vázquez-Alvarado, S.de J. Méndez-Gallegos, E. Troyo-Diéguez, C. Gallegos-Vázquez, and R.D. Valdez-Cepeda, 2017. Opuntia ficus-indica (L.) Mill. yield depends on nutrients and nutrient ratios. J. PACD, 13:1-9.

Barros, J.L. da; Donato, S. L. R., Gomes, V. M., Donato, P.E.R., Silva, J.A. da and Padilha Junior, M. C., 2016. Palma forrageira 'gigante' cultivada com adubação orgânica. Revista Agrotecnologia, 7:53-65, https://doi.org/10.12971/2179-5959/agrotecnologia. 7(1): 53-65

Bremner, J.M., 1965. Total nitrogen. In: Methods of Soil Analysis (Part 2). Black, C.A. (Ed), pp: 1149-78. American Society of Agronomy, Madison, USA.

Cantarella, H. and Nitrogênio, 2007. In: Novais, R. F., Alvarez V., V. H., Barros, N. F., Fontes, L. E. F. and Neves, J. C. L. (ed.). Fertilidade do Solo. 1.ed. Viçosa: Sociedade Brasileira de Ciência do Solo, 376-470.

Chapman, H.D. and P.F. Pratt, 1961. Methods of Analysis for Soils, Plants and Waters. Univ. of Calif., Division of Agric. Sci.

Claassens, A.S., and A.B. Wessels, 1997. The fertilizer requirements of cactus pear (Opuntia ficusindica) under summer rainfall conditions in South Africa. Acta Horticulturae, 438:83-95.

Clarke, G.M. and R.E. Kempson, 1997. Introduction to the design and analysis of experiments. Arnold, 1 St Ed. A Member of the Holder Headline Group, London, UK.

Claypool, L.L., K.S. Uriu, S. Leonard, and P.F. Lasker, 1971. The influence of cultural practices on the quality of "Dixon" cling peaches. University of California, Davis, Res. Prog. Rpt.

Dubeux, Jr.J.C.B., M.V.F. Santos, M.A. Lira, D.C. Santos, I. Farias, L.E. Lima, and R.L.C. Ferreira, 2006. Productivity of Opuntia ficus-indica (L) Miller under different N and P fertilization and plant population in northeast Brasil. Journal of Arid Environments, 67:357-372.

Duncan, D.B., 1955. Multiple range and multiple F test. Biometrics, 11:1-24.

Faquin, V., 1994. Mineral nutrition of plants. Lavras: ESAL-FAEPE: 227.

Ganeshamurthy, A.N., G.C. Satisha, and P. Patil, 2011. Potassium nutrition on yield and quality of fruit crops special emphasis on banana and grapes. Karnataka J. Agric. Sci., 24(1):29 - 38.

Gouws, C.A., E.N. Georgousopoulou, D.D. Mellor, A. McKune, and N. Naumovski, 2019. Effects of the consumption of prickly pear cacti (Opuntia spp.) and its products on blood glucose levels and insulin: A systematic review. Medicina, 55(138):1-18.

Inglese, P., 2010. Cactus pear Opuntia ficus-indica (L.) Mill. for fruit production: an overview. In Improved Utilization of Cactus Pear for Food, Feed, Soil and Water Conservation and Other Products in Africa, A. Nefzaoui, P. Inglese, and T. Belay, eds. Cactusnet Newsletter, special issue 12.

Jackson, M.L., 1958. Soil Chemical Analysis. P. 498. Constable Ltd. Co., London.

Leem, K.H., M.G. Kim, Y.T. Hahm, and H.K. Kim, 2016. Hypoglycemic effect of Opuntia ficus indica var. saboten is Due to Enhanced Peripheral Glucose Uptake through Activation of AMPK/p38 MAPK Pathway. Nutrients, 8(800):1-15.

Lucivania, R.L., T.G.F. Silva, A.M.R.F. Jardim, C.A.A. Souza, M.G. Queiroz, and J.N. Tabosa, 2018. Growth, water use and efficiency of forage cactus-sorghum intercropping under different water depths. Rev. Bras. Eng. Agríc. Amb., 22:113-8. 
Matt, J.K., 1968. Colorimetric determination of phosphorus in soil and plant material. Soil Sci., 109: 214-220.

Mengel, K. and E.A. Kirkby, 1978. Principles of plant nutrition. Int. Potash Inst., Berne Kalyani Publishers, New Delhi; Ludhignu Chap., 7: 140 - 159.

Mimouni, A., A. Ait Lhaj, and M. Ghazi, 2013. Mineral nutrition effect on cactus (Opuntia ficus spp.) growth and development. Acta Horticulturae, 995:213-20.

Neffar, S., H. Chenchouni, A. Beddiar and N. Redjel, 2013. Rehabilitation of degraded rangeland in drylands by Prickly pear (Opuntia ficus indica L.) plantations: Effect on soil and spontaneous vegetation. Ecol. Balk., 5(2):63-76.

Nefzaoui, A. and El Mourid, M., 2009. Cacti: A key-stone crop for the development of marginal lands and to combat desertification. Acta Horticulturae, 811: 365-372.10.17660 /Acta Hortic .2009 .811 .50

Nefzaoui, A., M. Louhaichi, and H. Salem, 2014. Cactus as a tool to mitigate drought and to combat desertification. Journal of Arid Land Studies, 24: 121-124.

Neto, J.D., R.M.de Matos, P.F.da Silva, A.S.de Lima, C.A.V.de Azevedo, and L.M.F. Saboya, 2020. Growth and yield of cactus pear under irrigation frequencies and nitrogen fertilization. R. Bras. Eng. Agric. Ambiental, 24(10):664-671.

Nijjar, G.S., 1985. Nutrition of Fruit Trees. Published by MrsUsha Raj Kumar for kalyani, New Delhi : 283-302.

Nobel, P.S., C.E. Russell, P. Felker, J.G. Medina, and E. Acuiia, 1987. Nutrient Relations and Productivity of Prickly Pear Cacti. Agron. J., 79: 550-555

Nobel, P.S., 1988. Environmental biology of agaves and cacti. Cambridge University Press. New York. USA.

Nobel, P.S. and B.R. Zutta, 2007. Temperature tolerances for stems and roots of two cultivated cacti, Nopalea cochenillifera and Opuntia robusta: acclimation, light and drought. Journal of Arid Environments, 72:633-642.

Novais, R.F. and J.W.V. Mello, Relação solo-planta. In: R.F. Novais, V.V.H. Alvarez, N.F. Barros, L.E.F. Fontes, and J.C.L. Neves, 2007. Fertilidade do Solo. 1.ed. Viçosa: Sociedade Brasileira de Ciência do Solo,133-204.

Parkinson, J.A. and S.E. Allen, 1975. A wet oxidation procedure suitable for the determination of nitrogen and mineral nutrients in biological material. Commun. Soil Sci. and Plant Analysis, 6(1): $1-11$.

Pinheiro, K.M., T.G.F.da Silva, H.F.deS. Carvalho, J.E.O. Santos, J.E.F. de Morais, S. Zolnier, and D.C.dos. Santos, 2014. Correlações do índice de área do cladódio com características morfogênicas e produtivas da palma forrageira. Pesquisa Agropecuária Brasileira, 49:939947. https://doi.org/10.1590/S0100- 204X2014001200004

Ramos, J.P.F., M.L.M.V. Leite, S. Oliveira Júnior, J.P. Nascimento, and E.M. Santos, 2011. Crescimento vegetativo de Opuntia fícus-indica em diferentes espaçamentos de plantio. Revista Caatinga, 24:41-48.

Santini, B.A. and M. Carlos, 2013. Does retained-seed priming drive the evolution of serotiny in drylands? An assessment using the cactus Mammillaria hernandezii. Am. J. Bot., 100:365-73 .

Silva, M.C., S.F. Santos, and M.V.F. Santos, 1998. Características de crescimento de cultivares de palma forrageira (Opuntia e Nopalea). In: CONGRESSO DE INICIAÇÃO CIENTÍFICA, Recife. Anais. Recife: Universidade Federal Rural de Pernambuco, 8:251.

Silva, J.A.da., P. Bonomo, S.L.R. Donato, A.J.V. Pires, R.C.C.D. Rosa, and E.R. Paulo, 2012. Composição mineral em cladódios de palma forrageira sob diferentes espaçamentos e adubações química. Revista Brasileira de Ciências Agrárias, 7: 866-875.

Silva, T.G.F.da., J.T. Araújo Primo, J.E.F.de. Morais, W.J.daS. Diniz, C.A.A.de. Souza, and M.daC. Silva, 2015. Crescimento e produtividade de clones de palma forrageira no semiárido e relações com variáveis meteorológicas. Revista Caatinga, 28:10-18.

Silva, J.A.da., S.L.R. Donato, P.E.R. Donato, E.dosS. Souza, M.C. Padilha Júnior, and A.A. Silva Junior, 2016. Yield and vegetative growth of cactus pear at different spacings and under chemical fertilizations. R. Bras. Eng. Agríc. Ambiental, 20(6):564-569. 
Silva, N.G.M., M.V.F. Santos, J.C.B. Dubeux Júnior, M.V. Cunha, M.A. Lira, and I. Ferraz, 2016a. Effects of planting density and organic fertilization doses on productive efficiency of cactus pear. Rev. Caatinga, 29(4):976-83.

Smith, D.M., B.C. Larson, M.J. Kelty, and P.M.S. Ashton, 1997. The practice of silviculture: applied forestry ecology. John Wiley and Sons, New York, 537.

Souza, T.C.de., M.V.F.dos. Santos, J.C.B.Jr. Dubeux, M.deA. Lira, D.C.dos. Santos, M.V.da. Cunha, L.E.de. Lima, and R.R.da. Silva, 2017. Productivity and nutrient concentration in spineless cactus under different fertilizations and plant densities. Rev. Bras. Cienc. Agrar., Recife, 12(4):555-560.

Stewart, W.M., D.W. Dibb, A.E. Johnston, and T.J. Smyth, 2005. Contribution of commercial fertilizer nutrients to food production. Agronomy Journal, 97:1-6.

Zegbe, J.A., A. Serna-Perez, and J. Mena-Covarrubias, 2014. Mineral nutrition enhances yield and affects fruit quality of 'Cristalina' cactus pear. Scientia Horticulturae , 167: 63-70. 